\title{
CLIMATE CHANGE AND CROP PRODUCTION CHALLENGES: AN OVERVIEW
}

\section{*Sushan Chowhan1, Shapla Rani Ghosh², Tushar Chowhan³, Md. Mahmudul Hasan ${ }^{4}$ and Md. Shyduzzaman Roni ${ }^{5}$}

\begin{abstract}
'Bangladesh Institute of Nuclear Agriculture (BINA), Sub-station, Khagrachari, Bangladesh; 2Department of ICT, Mawlana Bhashani Science and Technology University, Tangail, Bangladesh; ${ }^{3}$ Department of Geography and Environment, University of Dhaka, Bangladesh; ${ }^{4}$ Apex Organic Soya Industries Ltd., Sapmara, Gaibandha, Bangladesh; 5Department of Horticulture, Bangabandhu Sheikh Mujibur Rahman Agricultural University, Gazipur, Bangladesh
\end{abstract}

*Corresponding author: Sushan Chowhan; E-mail: sushan04@yahoo.com

\section{ARTICLE INFO}

\section{ABSTRACT}

Received

06.04.2016

Accepted

14.08.2016

Online

17 August 2016

Key words

Climate change,

Simulation models,

Stress,

Coping strategies
Climate change has heterogeneous effect on crop production. Potential yield of some crops were found to be decreasing in different simulation models. High temperature, drought, salinity, excessive rain fall are the major stresses faced by crops in a changing climatic condition. Coastal areas of Bangladesh are highly vulnerable to climate change. It was found that a total of $1,405.57$ MT yield are lost in different crops. Data shows the production trends of many crops remaining in a steady state or their increase is very slow compared to elapse of time. Some possible adaptation measures such as sorjan system, floating bed agriculture, growing crops in raised beds, harvesting rain water, cultivation of salt and flood tolerant crop varieties etc. were suggested to reduce possible climate change risk and to cope up with the current situation.

To cite this article: Chowhan S, SR Ghosh, T Chowhan, MM Hasan and MS Roni, 2016. Climate change and crop production challenges: an overview. Res. Agric. Livest. Fish., 3 (2): 251-269.

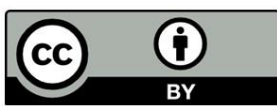

This is an open access article licensed under the terms of the Creative Commons Attribution 4.0 International License

www.agroaid-bd.org/ralf, E-mail: editor.ralf@gmail.com 


\section{INTRODUCTION}

Climate change and crop production are interrelated processes, both of which take place on a global scale. It describes how weather patterns will be affected around the globe. On the other hand, global warming describes an average temperature increase of the earth over time. These changes could be manifested in changes in climate averages as well as changes in extremes of temperatures and precipitation. It is likely that the changes will vary depending on region. Global warming is projected to have significant impacts on conditions affecting agriculture, including temperature, carbon dioxide, glacial run-off, precipitation and the interaction of these elements. These conditions determine the carrying capacity of the biosphere to produce enough food for the human population and domesticated animals. The overall effect of climate change on agriculture will depend on the balance of these effects.

At the same time, agriculture has been shown to produce significant effects on climate change, primarily through the production and release of greenhouse gases such as carbon dioxide, methane, and nitrous oxide, but also by altering the earth's land cover, which can change its ability to absorb or reflect heat and light, thus contributing to radiative forcing. Land use change such as deforestation and desertification, together with use of fossil fuels, are the major anthropogenic sources of carbon dioxide; agriculture itself is the major contributor to increasing methane and nitrous oxide concentrations in earth's atmosphere. Despite technological advances, such as improved varieties, genetically modified organisms, and irrigation systems, weather is still a key factor in agricultural productivity, as well as soil properties and natural communities. The effect of climate on agriculture is related to variabilities in local climates rather than in global climate patterns. The earth's average surface temperature has increased by $1.5^{\circ} \mathrm{F}\left(0.83^{\circ} \mathrm{C}\right)$ since 1880 (Anonymous, 2012). There is unequivocal evidence that the global climate is warming because of an increased concentration of greenhouse gases (GHG) in the earth atmosphere. According to the IPCC 4th assessment report (2007), continued GHG emission at or above current rates would cause further warming and induce changes in global climate system during the 21 st century that would very likely be larger than those observed during the 20th century. A 0.1 to $0.5 \mathrm{~m}$ rise in sea-level by the middle of this century (as predicted by most of the estimate) will pose a great threat to the livelihoods and agriculture in low-lying coastal areas of the world including about $1 / 5$ th of the total land area of Bangladesh. With a population of about 148 million, it is one of the poorest and most vulnerable countries in the world to disaster and climate change impacts. Different types of natural hazards including floods(e.g. river flood, urban flood and flash flood), cyclone and storm surges, tidal surges/intrusion of saline water, salinity, water-logging/submergence, drought, river bank erosion, tornadoes etc affect the country almost every year (Rahman, 2013). These catastrophic events significantly hinder the crop production systems. In Bangladesh, over $30 \%$ of the net cultivable area is in the coastal region. Out of 2.85 million hectares of the coastal and off-shore areas about 0.828 million hectares of the arable lands, which constitutes about 52.5 percent of the net cultivable area in 64 upazilas of 13 districts (Miah, 2010). But these vast cultivable areas is under great threat of vulnerabilities of the climate change and crop production is rapidly declining due to climate risk factors. Saline water intrusion, sea level rise, water logging, cyclone and storm surges are climatic hazards affecting the low lying coastal areas. Impacts of climate change and sealevel rise should have real consequences on the livelihoods of the coastal people as it would be affected by salinity intrusion, flooding, drainage congestion, cyclones, heavy storms and erosion of the land masses (WB, 2000; Agarwala et al., 2003).

The climate of Bangladesh is influenced by monsoon climate and characterized by high temperature, heavy rainfall, often-excessive humidity and marked seasonal variations. Although more than half of the area is north of the tropics, the effect of the Himalayan mountain chain is such as to make the climate more or less tropical throughout the year. The climate is controlled primarily by summer and winter winds, and partly by pre-monsoon (March to May) and post-monsoon (late October to November) circulation. The southwest monsoon originates over the Indian ocean, and carries warm, moist and unstable air. The easterly trade winds are also warm, but relatively drier. The northeast monsoon comes from the Siberian desert, retaining most of its pristine cold, and blows over the country, usually in gusts, during dry winter months. 
Environmental stress is the primary cause of crop losses worldwide, reducing average yields for most major crops by more than $50 \%$ (Bray et al., 2000). The tropical crop production environment is a mixture of conditions that varies with season and region. Climatic changes will influence the severity of environmental stress imposed on crops. Moreover, increasing temperatures, reduced irrigation water availability, flooding, and salinity will be major limiting factors in sustaining and increasing vegetable productivity. Extreme climatic conditions will also negatively impact soil fertility and increase soil erosion. Thus, additional fertilizer application or improved nutrient-use efficiency of crops will be needed to maintain productivity or harness the potential for enhanced crop growth due to increased atmospheric $\mathrm{CO}_{2}$. The response of plants to environmental stresses depends on the plant developmental stage and the length and severity of the stress (Bray, 2002). Plants may respond similarly to avoid one or more stresses through morphological or biochemical mechanisms (Capiati et al., 2006). Environmental interactions may make the stress response of plants more complex or influence the degree of impact of climate change. Temperature limits the range and production of many crops. In the tropics, high temperature conditions are often prevalent during the growing season and, with a changing climate, crops in this area will be subjected to increased temperature stress.

Drought, a slow onset disaster is the single most important factor affecting world food security and the catalyst of the great famines of the past (CGIAR 2003). The world's water supply is fixed, thus increasing population pressure and competition for water resources will make the effect of successive droughts more severe (McWilliam, 1986). Inefficient water usage all over the world and inefficient distribution systems in developing countries further decreases water availability. Water availability is expected to be highly sensitive to climate change and severe water stress conditions will affect crop productivity, Crop production is threatened by increasing soil salinity particularly in irrigated cropland which provide $40 \%$ of the world's food (FAO 2004). Excessive soil salinity reduces productivity of many agricultural crops, including most vegetables which are particularly sensitive throughout the ontogeny of the plant. Vegetable production occurs in both dry and wet seasons in the tropics. However, production is often limited during the rainy season due to excessive moisture brought about by heavy rain. For instance, most vegetables are highly sensitive to flooding.

\section{MATERIALS AND METHODS}

Scientific approach requires a close understanding of the subject matter. This paper mainly depends on the secondary data. Different published reports of different journals and reports mainly supported in providing data in this paper. This paper is completely a review paper. Therefore no specific method has been followed in preparing this paper. It has been prepared by Internet search, comprehensive studies of various articles published in different journals, books and proceedings available in the libraries of BSMRAU, BARI, BRRI and BARC. Valuable information has been collected through personal contact with respective resource personnel to enrich the paper. It compiled the all related information to prepare this paper.

\section{RESULTS AND DISCUSSION}

The impacts of climate change on crop production are expected to be widespread across the globe, although studies suggest that African agriculture is likely to be most affected due to heavy reliance on lowinput rainfed agriculture and due to its low adaptive capacity (Mertz et al., 2009). Broadly speaking, climate change is likely to impact crop productivity directly through changes in the growing environment, but also indirectly through shifts in the geography and prevalence of agricultural pests and diseases, associated impacts on soil fertility and biological function, and associated agricultural biodiversity. While many impact predictions tend towards the negative, increased $\mathrm{CO}_{2}$ will also contribute to enhanced fertilization, although there is significant debate as to the extent to which this may increase plant growth. The Inter-governmental Panel on Climate Change (IPCC, 2007) concluded that 'in mid- to high latitude regions, moderate warming benefits crop and pasture yields, but even slight warming decreases yields in seasonally dry and low-latitude regions (medium confidence)'. In IPCC language, moderate warming is in the range of $1-3^{\circ} \mathrm{C}$. Smallholder and subsistence farmers, pastoralists and artisanal fisher-folk will suffer complex, localized impacts of climate change (high confidence). Food and forestry trades are projected to increase in response to climate change with increased dependence on food imports for most developing countries (medium to low confidence). Warming beyond $2-3^{\circ} \mathrm{C}$ will likely result in yield declines in all areas. 
IPCC (2009) indicates that rising temperatures, drought, floods, desertification and weather extremes will severely affect crop production, especially in the developing world. Developing countries will be affected most for three reasons:

I. Climate change will have its most negative effects in tropical and subtropical regions;

II. Most of the predicted population growth to 2030 will occur in the developing world (United Nations Population Division DoEaSA, 2009); and

III. More than half of the overall work force in the developing world is involved in agriculture (FAO, 2005).

While anthropogenic effects on climate have been apparent for several decades, modeling future climate change is not an exact science due to the complexity and incomplete understanding of atmospheric processes. None the less, there is broad agreement that, in addition to increased temperatures, climate change will bring about regionally dependent increases or decreases in rainfall, an increase in cloud cover and increases in sea level. Extreme climate events will also increase in intensity or frequency, such as higher maximum temperatures, more intense precipitation events, increased risk and duration of drought, and increased peak wind intensities of cyclones. Predictions in sea level rise indicate that this will continue for centuries after temperatures stabilize, causing flooding of coastal lands and salinization of soils and subsurface water in coastal regions.

Models of crop response to climate change mainly consider temperature, soil moisture and increased carbon dioxide. However, many other processes not easily incorporated into models could potentially have significant effects including: pests and diseases, brief exposures of crops to very high temperatures, elevated ozone, loss of irrigation water, and increase in inter-annual climate variability associated with monsoons and phenomena like El Niño. The model outputs, while encompassing a wide range of potential outcomes, tend to have the following in common:

- The yield potential of staple foods will decline in most production environments and commodity prices will rise

- While projections for a few countries with northerly latitudes indicate net positive impacts of climate change, projections for most developing countries are negative.

- Only 'best-case' scenarios predict no net effect of climate change on global cereal yields by 2030 but predictions beyond that time frame are much more pessimistic.

\section{A. Simulation Models}

Models are a mathematical representation of a real world system. The use of models is very common in other disciplines, including the airplane industry, automobile industry, civil, industrial and chemical engineering etc. The use of models in agriculture and environmental sciences is not very common.

Crop simulation models integrate current scientific knowledge from many different disciplines, including crop physiology, plant breeding, agronomy, agro meteorology, soil physics, soil chemistry, pathology and entomology. Crop simulation models in general calculate or predict crop yield as a function of weather conditions, soil conditions and crop management scenarios

\section{SRES (Special Report Emissions Scenarios)}

It is a report by IPCC that was published in 2000. The greenhouse gas emissions scenarios described in the report have been used to make projections of possible future climate change.

\section{GCM (Global Circulation Models)}

GCMs and global climate models are widely applied for weather forecasting, understanding the climate, and projecting climate change.

\section{RCM (Regional Climate Models)}

This modeling technique consists of using initial conditions, time-dependent lateral meteorological conditions and surface boundary conditions to drive high-resolution RCMs. The driving data is derived from GCMs (or analyses of observations) and can include GHG and aerosol forcing. One of the primary advantages of these techniques is that they are computationally inexpensive, and thus can easily be applied to output from different GCM experiments. Another advantage is that they can be used to provide local information, which can be most needed in many climate change impact applications. 


\section{PRECIS (Providing Regional Climate for Impacts Studies)}

It is a regional climate modeling system designed to run on a Linux based PC. PRECIS can be applied to any area of the globe to generate detailed climate change projections.

\section{VAR (Vector Auto Regression)}

It is a statistical model used to capture the linear interdependencies among multiple time series. VAR models generalize the univariate auto regression (AR) models. All the variables in a VAR are treated symmetrically; each variable has an equation explaining its evolution based on its own lags and the lags of all the other variables in the model. It does not require expert knowledge.

\section{DSSAT (Decision Support System for Agro technology Transfer)}

The DSSAT-CSM simulates growth, development and yield of a crop growing on a uniform area of land under prescribed or simulated management as well as the changes in soil water, carbon, and nitrogen that take place under the cropping system over time. The DSSAT-CSM is. The DSSAT helps decision makers by reducing the time and human resources required for analyzing complex alternative decisions (Tsuji et al., 1998).

\section{APSIM (Agricultural Production Systems Simulator)}

It is used to simulate biophysical processes in farming systems, particularly to the economic and ecological outcomes of management practices in the face of climate risk.

\section{Data Sets Required for Model Calibration and Validation}

Daily weather data: Rainfall, max and min temperatures, solar radiation or sunshine hours.

Soil profile characterization data (one time activity — data to be collected from soil survey reports): Soil texture by horizon, bulk density, fraction stones, organic carbon, soil pH (water), horizon thickness and depth, root growth distribution, surface characteristics such as soil color, slope, permeability, drainage class, soil series name.

Management data: Crop, cultivar, planting date, seedling rate, plant spacing, row spacing, planting depth, irrigation (dates, amounts, type and method of irrigation), fertilizer applied (dates, amounts, type of material, method of application), chemical application (date, amount, type, method of application), tillage/ intercultural operations (dates, depth, equipment used), organic fertilizer (date, amount, type and method of application), thinning and weeding (date and method).

Initial soils data (to be collected at sowing of a crop): Initial soil water measurements up to maximum soil depth $(1.5 \mathrm{~m})$ and soil sampling at $30 \mathrm{~cm}$ depth intervals, Initial soil fertility up to $1.5 \mathrm{~m}$ at $30 \mathrm{~cm}$ depth intervals. Soil samples should be analyzed for $\mathrm{NH}_{4}, \mathrm{NO}_{3}, \mathrm{P}, \mathrm{K}, \mathrm{pH}$ and organic $\mathrm{C}$ and $\mathrm{N}$, Soil surface residue, amount and composition ( $\mathrm{N}$ and $\mathrm{C}$ content).

Soil water measurements: At every 10 to 15 day interval up to maximum soil depth $(1.5 \mathrm{~m})$ at $30 \mathrm{~cm}$ depth interval using gravimetric method if others not available

Vegetative and reproductive development (crop-specific visual observations only): Observations taken at every 2 or 3 days. Emergence date, vegetation stages $\left(V_{1}, V_{2}, V_{3}--------V_{n}\right)$ and reproductive stages $\left(R_{1}, R_{3}\right.$, $\mathrm{R}_{5}, \mathrm{R}_{6}------\mathrm{R}_{8}$ ).

Crop growth analysis (crop-specific, could change with crop): Plants sampled every two weeks and sample harvested area is determined $(1 \mathrm{~m} 2)$, no. of plant sampled, total above ground biomass, weights of leaf, petioles, pods and seeds; leaf area (can be done on a sub-sample), no. of pods, no. of seeds and nitrogen concentration (optional) etc. data are collected.

Yield and yield components at harvest (crop specific, could change with crop): Harvest date, harvest density (plants/m2), harvest area, total above ground biomass, pod yield (seed + shell), seed yield, 1000 seed weight, 1000 pod weight recorded.

\section{B. Climatic change scenarios}

The climate in Bangladesh is changing and it is becoming more unpredictable every year. The impacts of higher temperatures, more variable precipitation, more extreme weather events, and sea level rise are already felt in Bangladesh and will continue to intensify. Climate change poses now-a-days severe threat mostly in crop sector and food security among all other affected sectors. Crop yields are predicted to fall by up to $30 \%$, 
creating a very high risk of hunger and only sustainable climate-resilient crop production is the key to enabling farmers to adapt and increase food security (Climate Change Cell, 2007). The coastal area of Bangladesh is naturally susceptible to disaster.

Table 1. Climate change scenario for Bangladesh

\begin{tabular}{|c|c|c|c|c|c|c|c|c|}
\hline \multirow{2}{*}{ Model } & \multirow{2}{*}{ Year } & \multicolumn{3}{|c|}{$\begin{array}{l}\text { Temperature change }\left({ }^{\circ} \mathrm{C}\right) \\
\text { Mean (standard deviation) }\end{array}$} & \multicolumn{3}{|c|}{$\begin{array}{l}\text { Precipitation change (\%) Mean } \\
\text { (standard deviation) }\end{array}$} & \multirow{2}{*}{$\begin{array}{l}\text { Sea } \\
\text { Level } \\
\text { Rise (cm) }\end{array}$} \\
\hline & & Annual & DJF & JJA & Annual & DJF & JJA & \\
\hline GCM & 2030 & 1.0 & 1.1 & 0.8 & 5 & -2 & 6 & \multirow{3}{*}{14} \\
\hline \multirow{2}{*}{ PRECIS } & 2030 (Max) & 0.3 & -0.02 & $1.3^{*}$ & \multirow{2}{*}{4} & \multirow{2}{*}{-8.7} & \multirow{2}{*}{3.8} & \\
\hline & 2030 (Min) & 1.18 & 0.65 & $1.78^{*}$ & & & & \\
\hline GCM & 2050 & 1.4 & 1.6 & 1.1 & 6 & -5 & 8 & \\
\hline \multirow{2}{*}{ PRECIS } & 2050 (Max) & 0.2 & 0.07 & $0.89^{*}$ & \multirow{2}{*}{2.3} & \multirow{2}{*}{-4.7} & \multirow{2}{*}{3.0} & \multirow[t]{2}{*}{32} \\
\hline & 2050 (Min) & 1.24 & 0.59 & $1.65^{\star}$ & & & & \\
\hline
\end{tabular}

Note: * JJAS (June, July, August, September); DJF= December January February, JJA= June July August.

(Source: Miah, 2010)

\section{Drought}

Unpredictable drought is the single most important factor affecting world food security and the catalyst of the great famines of the past (CGIAR 2003). The world's water supply is fixed, thus increasing population pressure and competition for water resources will make the effect of successive droughts more severe (McWilliam 1986). Inefficient water usage all over the world and inefficient distribution systems in developing countries further decreases water availability. Water availability is expected to be highly sensitive to climate change and severe water stress conditions will affect crop productivity, particularly that of vegetables. In combination with elevated temperatures, decreased precipitation could cause reduction of irrigation water availability and increase in evapotranspiration, leading to severe crop water-stress conditions (IPCC 2001). Vegetables, being succulent products by definition, generally consist of greater than $90 \%$ water (AVRDC 1990). Thus, water greatly influences the yield and quality of crops; drought conditions drastically reduce crop productivity. Drought stress causes an increase of solute concentration in the environment (soil), leading to an osmotic flow of water out of plant cells. This leads to an increase of the solute concentration in plant cells, thereby lowering the water potential and disrupting membranes and cell processes such as photosynthesis. The timing, intensity, and duration of drought spells determine the magnitude of the effect of drought.

Table 2. Drought prone areas (in mha) of Bangladesh

\begin{tabular}{|llll|}
\hline Drought Class & Rabi & Pre-Kharif & Kharif \\
\hline Very Severe & 0.446 & 0.403 & 0.344 \\
Severe & 1.71 & 1.15 & 0.74 \\
Moderate & 2.95 & 4.76 & 3.17 \\
Slight & 4.21 & 4.09 & 2.90 \\
No Drought & 3.17 & 2.09 & 0.68 \\
Non-T. aman & & & 4.71 \\
\hline
\end{tabular}

Source: Drought Manual, BARC, 2003 


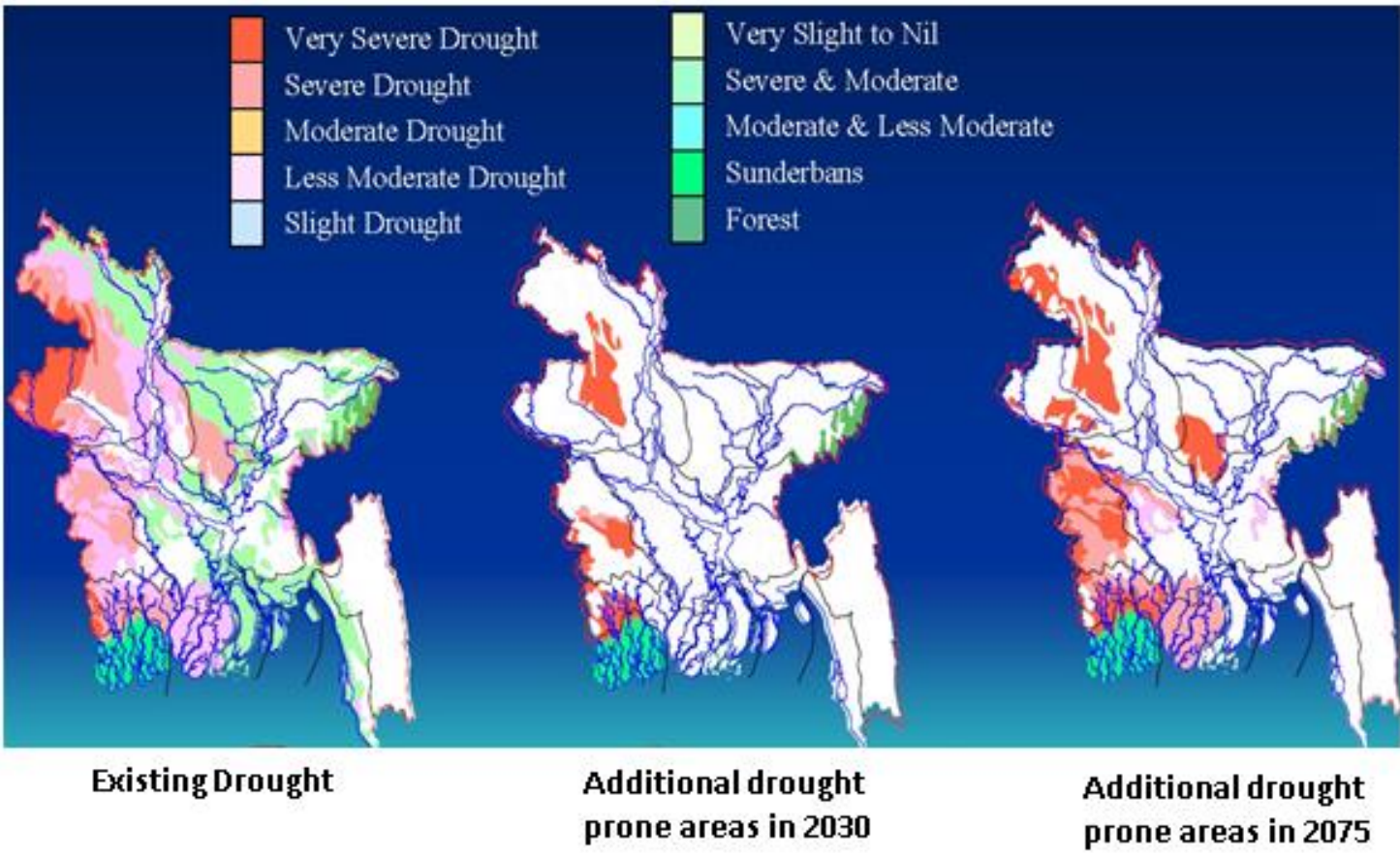

Figure 1. Maps showing existing drought and drought in the year 2030 and 2075.

(Source: Sultana et. al., 2008)

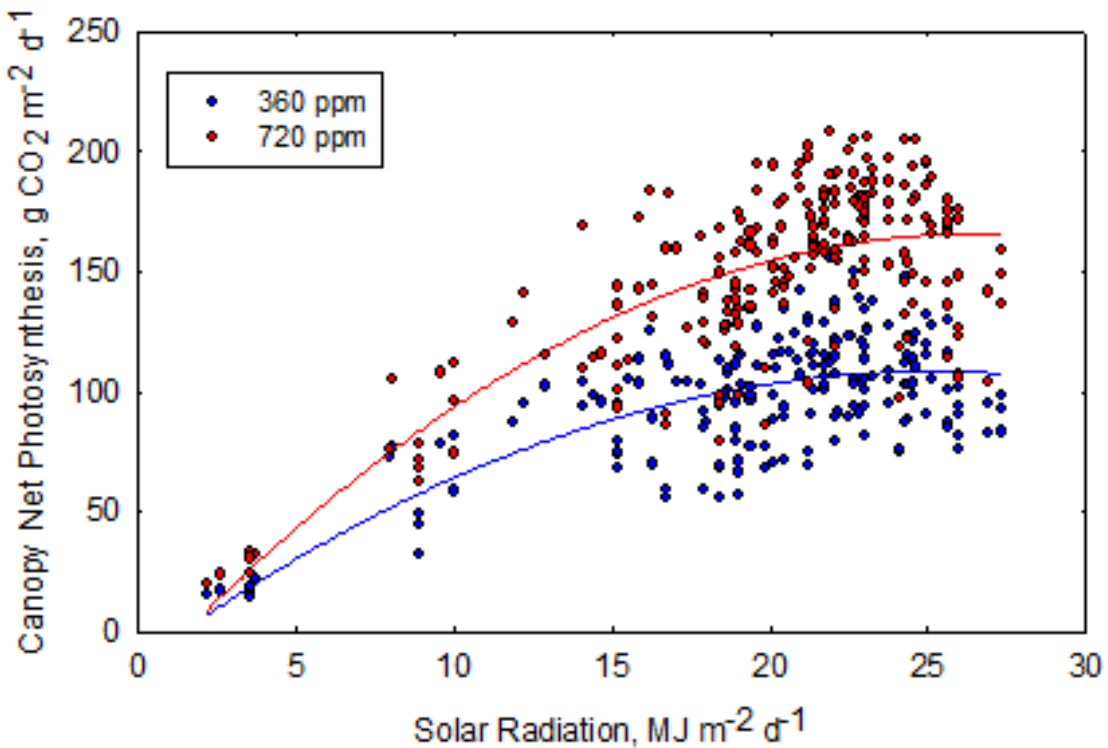

Figure 2. Cotton photosynthesis-solar radiation.

(Source: Baker and Allen, 1993)

\section{High temperatures}

Temperature limits the range and production of many crops. In the tropics, high temperature conditions are often prevalent during the growing season and, with a changing climate, crops in this area will be subjected to increased temperature stress. Analysis of climate trends in tomato growing locations suggests that temperatures are rising and the severity and frequency of above optimal temperature episodes will increase in the coming decades (Bell et al., 2000). Vegetative and reproductive processes are strongly modified by temperature alone or in conjunction with other environmental factors (Abdalla and Verkerk, 1968). 
High temperature stress disrupts the biochemical reactions fundamental for normal cell function in plants. It primarily affects the photosynthetic functions of higher plants (Weis and Berry, 1988). High temperatures can cause significant losses in productivity due to reduced fruit set, and smaller and lower quality fruits (Stevens and Rudich, 1978). Pre-anthesis temperature stress is associated with developmental changes in the anthers, particularly irregularities in the epidermis and endothesium, lack of opening of the stromium, and poor pollen formation (Sato et al., 2002). In pepper, high temperature exposure at the pre-anthesis stage did not affect pistil or stamen viability, but high post-pollination temperatures inhibited fruit set, suggesting that fertilization is sensitive to high temperature stress (Erickson and Markhart, 2002). Hazra et al., (2007) summarized the symptoms causing fruit set failure at high temperatures in tomato; this includes bud drop, abnormal flower development, poor pollen production, dehiscence, and viability, ovule abortion and poor viability, reduced carbohydrate availability, and other reproductive abnormalities. In addition, significant inhibition of photosynthesis occurs at temperatures above optimum, resulting in considerable loss of potential productivity.

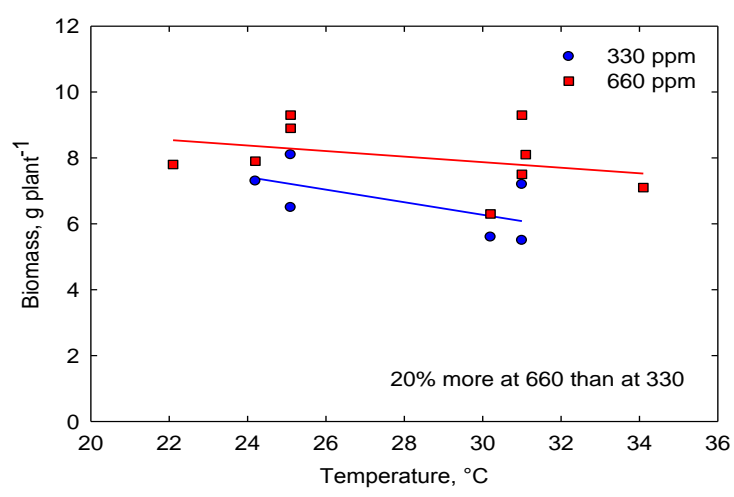

Figure 3. Rice growth in different temperature and $\mathrm{CO}_{2}$ concentration.

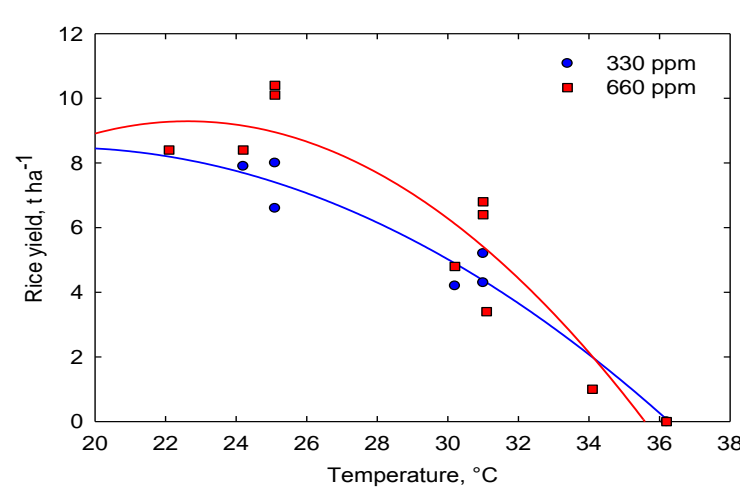

Figure 4. Variation in rice yield in different $\mathrm{CO}_{2}$ concentration.

(Source: Baker and Allen, 1993)

\section{Effect of climate change on biomass and grain yield of wheat}

Without the direct effect of $\mathrm{CO}_{2}$ the model predicted that all three climate change scenarios significantly increases biomass production compared to the baseline (Table 3), with A1B increasing the most $(28 \%)$ followed by $\mathrm{B} 1(16 \%)$ and $\mathrm{A} 2(12 \%)$. The combined effect (climate and $\mathrm{CO}_{2}$ ) increased biomass production much more, with A1B increasing the most (74\%) and A2 (55\%) and B1 (41\%) being similar. Increased $\mathrm{CO}_{2}$ concentrations of 220 and 120 ppm resulted in increased biomass production of $43-45 \%$ and $25 \%$, respectively. The effect of the climate change scenarios on grain yield shows the same trend as biomass with a slightly higher increase rate.

Table 3. Effects of climate change on biomass and grain production of wheat

\begin{tabular}{|llll|}
\hline Scenario & CO2 $\mathbf{~ p p m}$ & Biomass $\mathbf{~ K g / h a )}$ & Grain Yield (Kh/ha) \\
\hline Baseline & 330 & $5039 f$ & $2467 f$ \\
A1B & 330 & $6463 \mathrm{~d}$ & $3167 \mathrm{~d}$ \\
A1B & 550 & $8753 \mathrm{a}$ & $4349 \mathrm{a}$ \\
A2 & 330 & $5651 \mathrm{e}$ & $2834 \mathrm{e}$ \\
A2 & 550 & $7813 \mathrm{~b}$ & $3978 \mathrm{~b}$ \\
B1 & 330 & $5856 \mathrm{e}$ & $2880 \mathrm{e}$ \\
B1 & 450 & $7104 \mathrm{c}$ & $3520 \mathrm{c}$ \\
\hline
\end{tabular}

Note: Baseline $=1961-1990, \mathrm{~A} 1 \mathrm{~B}=3.2^{\circ} \mathrm{C}, \mathrm{A} 2=3.6^{\circ} \mathrm{C}, \mathrm{B} 1=2.7^{\circ} \mathrm{C}$ more than the baseline temperature (Source: Wang et. al., 2011) 
Table 4. Rice and wheat production under different climate change scenarios

\begin{tabular}{|c|c|c|c|c|c|c|c|c|}
\hline \multirow[b]{2}{*}{ Simulation } & \multicolumn{2}{|c|}{ HYV Aus } & \multicolumn{2}{|c|}{ HYV Aman } & \multicolumn{2}{|c|}{ HYV Boro } & \multicolumn{2}{|c|}{ Wheat } \\
\hline & $\begin{array}{l}\text { ('000' } \\
\text { tones) }\end{array}$ & $\begin{array}{l}\text { Percent } \\
\text { Change }\end{array}$ & $\begin{array}{l}\text { ('000' } \\
\text { tones) }\end{array}$ & $\begin{array}{l}\text { Percent } \\
\text { Change }\end{array}$ & $\begin{array}{l}\text { ('000' } \\
\text { tones) }\end{array}$ & $\begin{array}{l}\text { Percent } \\
\text { Change }\end{array}$ & $\begin{array}{l}\text { ('000' } \\
\text { tones }\end{array}$ & $\begin{array}{l}\text { Percent } \\
\text { Change }\end{array}$ \\
\hline $\begin{array}{l}\text { Baseline (1994- } \\
95)\end{array}$ & 702 & 0 & 4,484 & 0 & 6,200 & 0 & 890 & 0 \\
\hline CCCM & 512 & -27 & 4,170 & -7 & 6,014 & -3 & 712 & -20 \\
\hline GFDL & 512 & -27 & 3,901 & -13 & 5,766 & -7 & 347 & -61 \\
\hline $\begin{array}{l}330 \mathrm{ppmv} \\
\mathrm{CO}_{2}+20^{\circ} \mathrm{C}\end{array}$ & 569 & -19 & 3,901 & -13 & 5,952 & -4 & 561 & -37 \\
\hline $\begin{array}{l}330 \mathrm{ppmv} \\
\mathrm{CO}_{2}+40^{\circ} \mathrm{C}\end{array}$ & 435 & -38 & 3,363 & -25 & 5,766 & -7 & 285 & -68 \\
\hline $\begin{array}{l}580 \mathrm{ppmv} \\
\mathrm{CO} 2+00^{\circ} \mathrm{C}\end{array}$ & 920 & 31 & 5,605 & -25 & 7,626 & 23 & 1,228 & 38 \\
\hline $\begin{array}{l}580 \mathrm{ppmv} \\
\mathrm{CO}_{2}+20^{\circ} \mathrm{C}\end{array}$ & 793 & 13 & 4,977 & 11 & 7,440 & 20 & 881 & -1 \\
\hline $\begin{array}{l}580 \mathrm{ppmv} \\
\mathrm{CO}_{2}+40^{\circ} \mathrm{C}\end{array}$ & 660 & -6 & 4,529 & 1 & 7,192 & 16 & 534 & -40 \\
\hline $\begin{array}{l}660 \mathrm{ppmv} \\
\mathrm{CO}_{2}+00^{\circ} \mathrm{C}\end{array}$ & 983 & 40 & 5,964 & 33 & 8,060 & 30 & 1,317 & 48 \\
\hline $\begin{array}{l}660 \mathrm{ppmv} \\
\mathrm{CO}_{2}+20^{\circ} \mathrm{C}\end{array}$ & 856 & 22 & 5,336 & 19 & 7,874 & 27 & 970 & 9 \\
\hline $\begin{array}{l}660 \mathrm{ppmv} \\
\mathrm{CO}_{2}+40^{\circ} \mathrm{C}\end{array}$ & 730 & 4 & 4,888 & 9 & 7,626 & 23 & 614 & -31 \\
\hline
\end{tabular}

$\mathrm{CCCM}=$ Canadian Climate Centre Model.

(Source: Karim et al., 1998)

GFDL $=$ Geophysical Fluid Dynamics laboratory.

Table 5. Temperature effects on crop yield

\begin{tabular}{|lllllll|}
\hline Crop & $\begin{array}{l}\text { T opt, } \\
{ }^{\circ} \mathrm{C}\end{array}$ & $\begin{array}{l}\text { T max, } \\
{ }^{\circ} \mathrm{C}\end{array}$ & $\begin{array}{l}\text { Yield } \\
\text { at T opt, } \\
(\mathrm{t} / \mathrm{ha})\end{array}$ & $\begin{array}{l}\text { Yield } \\
\text { at 28 } \\
\text { (t/ha) }\end{array}$ & $\begin{array}{l}\text { Yield at } \\
\mathbf{3 2}^{\circ} \mathbf{C} \\
(\mathrm{t} / \mathrm{ha})\end{array}$ & $\begin{array}{l}\text { \% decrease } \\
\left(28 \text { to } 32^{\circ} \mathrm{C}\right)\end{array}$ \\
\hline Rice & 25 & 36 & 7.55 & 6.31 & 2.93 & 54 \\
Soybean & 28 & 39 & 3.41 & 3.41 & 3.06 & 10 \\
Dry bean & 22 & 32 & 2.87 & 1.39 & 0.00 & 100 \\
Peanut & 25 & 40 & 3.38 & 3.22 & 2.58 & 20 \\
Grain sorghum & 26 & 35 & 12.24 & 11.75 & 6.95 & 41 \\
\hline
\end{tabular}

Source: Reddy et. al., 2005

Table 6. Climate change responses of sorghum (Location: Parbhani, Maharashtra)

\begin{tabular}{|c|c|c|c|c|c|}
\hline \multicolumn{2}{|c|}{$\begin{array}{l}\text { Variety: CSH } 15 \\
\text { Mean seasonal temperature: } 29^{\circ} \mathrm{C}\end{array}$} & \multicolumn{3}{|c|}{$\begin{array}{l}\text { Rainfall: } 790 \mathrm{~mm} \\
\text { AWC of soil: } 120 \mathrm{~mm}\end{array}$} & \multirow{3}{*}{$\mathrm{HI}(\%)$} \\
\hline \multirow[t]{2}{*}{ Scenarios } & \multirow{2}{*}{$\begin{array}{l}\text { Crop duration } \\
\text { (days) }\end{array}$} & \multicolumn{3}{|c|}{ Grain Yield } & \\
\hline & & $\mathrm{tha}^{-1}$ & $\%$ Change & CV (\%) & \\
\hline Control & 94 & 4.12 & 0 & 11 & 35 \\
\hline + Temp. & 82 & 2.90 & -27 & 18 & 33 \\
\hline + Temp.+RF & 82 & 3.05 & -26 & 16 & 33 \\
\hline
\end{tabular}

Data period: 1969-2007

Source: Singh et. al., 2009 


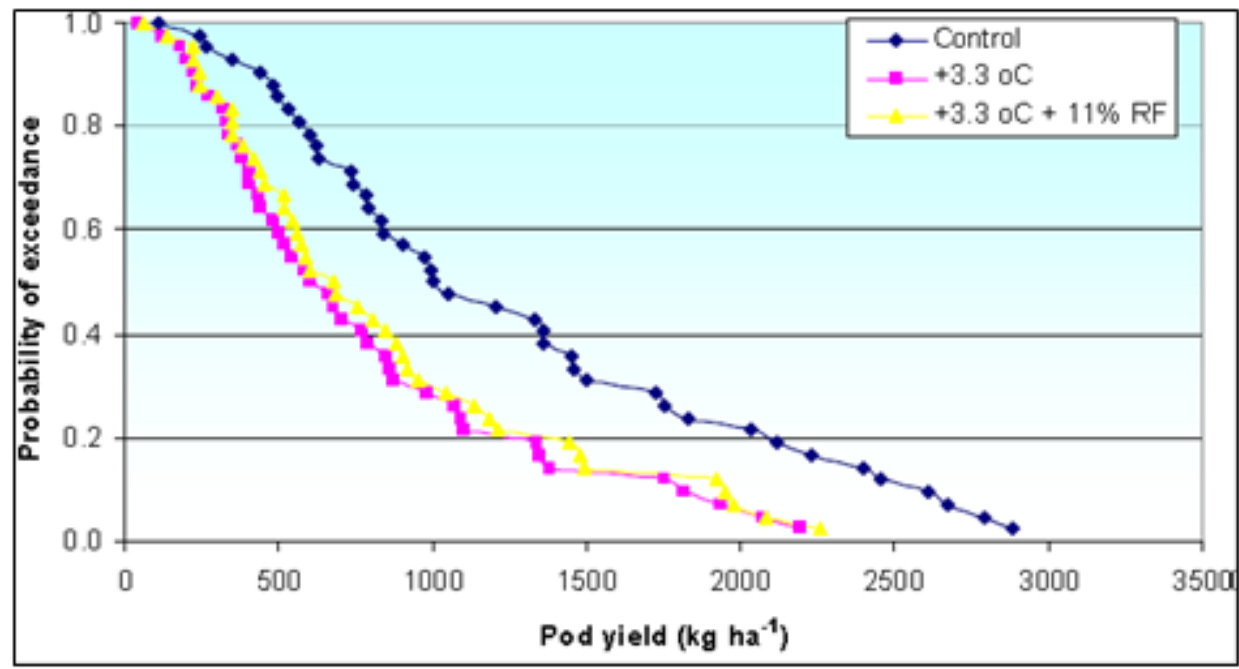

Figure 5. Probability distribution of yield under climate change (Groundnut - Anantapur). (Source: Singh et. al., 2009)

Table 7. Simulated effect of climate changeon ICRISAT crops

\begin{tabular}{|llll|}
\hline Crop & \multicolumn{2}{l|}{ \% change in grain yield } & \\
\cline { 2 - 4 } & +Temp. & $+\mathrm{CO}_{2}$ & Net change \\
\hline Sorghum & $-(27$ to $55 \%)$ & $+(0$ to $10 \%)$ & $-(22$ to $50 \%)$ \\
P. millet & $-(38$ to $56 \%)$ & $+(0$ to $10 \%)$ & $-(33$ to $51 \%)$ \\
Groundnut & $-(38$ to $44 \%)$ & $+(10$ to $20 \%)$ & $-(23$ to $29 \%)$ \\
Pigeon pea & $-(23$ to $26 \%)$ & $+(10$ to $20 \%)$ & $-(8$ to $11 \%)$ \\
Chick pea & $-(22$ to $24 \%)$ & $+(10$ to $20 \%)$ & $-(7$ to $9 \%)$ \\
\hline
\end{tabular}

Source: Tubiello et al., 2007

When adaptation is not considered, most of the major potato producing countries would suffer great losses in potential potato yield. Bolivia is the only country where potential yield would increase without adaptation, and with adaptation it is predicted to increase a staggering $77 \%$. In most other major potato producing countries, adaptation mitigates a large part of the climate change induced yield loss. In Iran, for example, yield loss decreases from $48 \%$ to $13 \%$. China, Peru, Russia, and the USA are other notable examples of countries where adaptation could mitigate much of the negative effects of global warming. When considering adaptation, Bangladesh, Brazil, Colombia, and Ukraine have the largest decrease in potential yield (more than $20 \%$ in 2040-59). The percentage of area with yield increase (Table 8 ) reflects the possibility to mitigate the effect of climate change by shifting the location of production with existing potato growing regions. It is particularly high ( $>30 \%$ ) in Argentina, Canada, China, Japan, UK, Russia, and Spain.

\section{Effect of climate change on rice production in Bangladesh}

Tables 9 and 10 show predicted yields of BR3 and BR14 boro rice varieties, respectively at 12 locations of Bangladesh in the years 2008, 2030, 2050 and 2070. These predictions have been made using a fixed concentration of atmospheric $\mathrm{CO}_{2}$ of $379 \mathrm{ppm}$ (the value reported for the year 2005 in the fourth assessment report of IPCC) and for planting date of 15 January. The tables show significant reduction in rice yield in the future due to predicted changes in climatic condition. Compared to 2008, predicted average reductions of BR3 variety for the 12 selected locations are about $11 \%$ for the year $2030,21 \%$ for 2050 and $54 \%$ for 2070 . The corresponding reductions for BR14 variety are about 14\%, 25\% and 58\% for the years 2030, 2050 and 2070, respectively. Some regional variation could also be observed in the predictions, with somewhat higher reductions predicted for central, southern and south-western regions. 
Table 8. Potato area and changes in potential potato yield induced by climate change in the 2040-59 and the percentage of the potato area in a country where potential potato yield will increase

\begin{tabular}{|llllll|}
\hline \multirow{2}{*}{ Country } & Potato area & \multicolumn{2}{l|}{ Change in potential yield (\%) } & \multicolumn{2}{l|}{ Areas with yield increase (\% of cells) } \\
\cline { 3 - 5 } & $(\mathbf{1 0 0 0}$ ha) & Without & With & Without Adaptation & With \\
& & Adaptation & Adaptation & & Adaptation \\
\hline China & 3430 & -22.2 & -2.5 & 8.5 & 30.7 \\
Russia & 3289 & -24.0 & -8.8 & 12.4 & 48.4 \\
Ukraine & 1534 & -30.3 & -24.8 & 0.0 & 2.7 \\
Poland & 1290 & -19.0 & -16.1 & 0.0 & 2.4 \\
India & 1253 & -23.1 & -22.1 & 0.4 & 2.0 \\
Belarus & 692 & -18.8 & -16.6 & 0.0 & 0.0 \\
United States & 548 & -32.8 & -5.9 & 1.4 & 20.1 \\
Germany & 300 & -19.6 & -15.5 & 0.0 & 0.0 \\
Peru & 263 & -5.7 & 5.8 & 8.3 & 13.9 \\
Romania & 262 & -26.0 & -9.9 & 0.0 & 19.2 \\
Turkey & 207 & -36.7 & -17.1 & 0.0 & 10.4 \\
Netherlands & 181 & -20.0 & -10.9 & 0.0 & 0.0 \\
Brazil & 177 & -23.2 & -22.7 & 0.0 & 0.0 \\
United Kingdom & 169 & -6.2 & 8.1 & 50.0 & 57.1 \\
France & 168 & -18.7 & -6.9 & 4.5 & 29.9 \\
Colombia & 167 & -32.5 & -30.6 & 4.5 & 4.5 \\
Kazakhstan & 165 & -38.4 & -12.4 & 2.3 & 9.4 \\
Iran & 161 & -48.3 & -13.3 & 0.0 & 21.4 \\
Canada & 155 & -15.7 & 4.6 & 17.9 & 55.5 \\
Spain & 142 & -31.4 & -6.6 & 0.0 & 37.5 \\
Bangladesh & 140 & -25.8 & -24.0 & 0.0 & 0.0 \\
Bolivia & 131 & 8.4 & 76.8 & 22.6 & 29.0 \\
Lithuania & 126 & -13.7 & -9.2 & 0.0 & 0.0 \\
Argentina & 115 & -12.9 & 0.5 & 11.4 & 35.2 \\
Nepal & 115 & -18.3 & -13.8 & 0.0 & 41.2 \\
Japan & 102 & -17.4 & -0.9 & 8.8 & \\
\hline Source:H & & & & \\
\hline
\end{tabular}

Source: Hijmans, 2003

Table 9. Predicted yield of BR 3 variety of boro rice $\left(\mathrm{kg} \mathrm{ha}^{-1}\right)$ at 12 selected locations for the years 2008, 2030, 2050 and 2070

\begin{tabular}{|c|c|c|c|c|c|c|c|c|}
\hline $\begin{array}{l}\text { Station } \\
\text { Name }\end{array}$ & Cultivar & 2008 & 2030 & 2050 & 2070 & $\begin{array}{l}\% \\
\text { change } \\
\text { in yield } \\
\text { for } 2030\end{array}$ & $\begin{array}{l}\% \text { change } \\
\text { in yield for } \\
2050\end{array}$ & $\begin{array}{l}\text { \% change } \\
\text { in yield for } \\
2070\end{array}$ \\
\hline Rajshahi & BR3 & 3063 & 4083 & 3265 & 1785 & 33.3 & 6.59 & -41.7 \\
\hline Bogra & BR3 & 5741 & 5119 & 4070 & 2036 & -10.8 & -29.1 & -64.5 \\
\hline Dinajpur & BR3 & 6848 & 4824 & 4364 & 2692 & -29.6 & -36.3 & -60.7 \\
\hline Mymensingh & BR3 & 5995 & 5275 & 4455 & 2739 & -12.0 & -25.7 & -54.3 \\
\hline Tangail & BR3 & 5487 & 5160 & 3874 & 1938 & -5.95 & -29.4 & -64.7 \\
\hline Jessore & BR3 & 5571 & 4432 & 4583 & 1997 & -20.4 & -17.7 & -64.2 \\
\hline Satkhira & BR3 & 4700 & 4364 & 3603 & 2066 & -7.14 & -23.3 & -56.0 \\
\hline Barisal & BR3 & 6043 & 4006 & 3971 & 2091 & -33.7 & -34.3 & -65.4 \\
\hline adaripur & BR3 & 4582 & 4017 & 3647 & 2186 & -12.3 & -20.4 & -52.3 \\
\hline Chandpur & BR3 & 5975 & 5455 & 4039 & 2772 & -8.70 & -32.4 & -53.6 \\
\hline Comilla & BR3 & 6115 & 5987 & 4456 & 3075 & -2.09 & -27.1 & -49.7 \\
\hline Sylhet & BR3 & 5960 & 5117 & 5750 & 3595 & -14.1 & -3.52 & -39.7 \\
\hline
\end{tabular}

Source: Basak et.al., 2010 
Table 10. Predicted yield of BR 14 variety of boro rice $\left(\mathrm{kg} \mathrm{ha}^{-1}\right)$ at 12 selected locations for the years 2008, 2030,2050 and 2070

\begin{tabular}{|lllllllll|}
\hline $\begin{array}{l}\text { Station } \\
\text { Name }\end{array}$ & Cultivar & 2008 & $\mathbf{2 0 3 0}$ & $\mathbf{2 0 5 0}$ & $\mathbf{2 0 7 0}$ & $\begin{array}{l}\text { \% change } \\
\text { in yield } \\
\text { for 2030 }\end{array}$ & $\begin{array}{l}\text { \% change } \\
\text { in yield } \\
\text { for 2050 }\end{array}$ & $\begin{array}{l}\text { \% change } \\
\text { in yield } \\
\text { for 2070 }\end{array}$ \\
\hline Rajshahi & BR14 & 2334 & 2771 & 2392 & 1148 & 18.7 & 2.48 & -50.8 \\
Bogra & BR14 & 4306 & 3668 & 2637 & 1398 & -14.8 & -38.8 & -67.5 \\
Dinajpur & BR14 & 5047 & 3374 & 3023 & 1656 & -33.1 & -40.1 & -67.2 \\
Mymensingh & BR14 & 4353 & 3790 & 3186 & 1873 & -12.9 & -26.8 & -57.0 \\
Tangail & BR14 & 4104 & 3883 & 2565 & 1297 & -5.38 & -37.5 & -68.4 \\
Jessore & BR14 & 4032 & 3160 & 3153 & 1305 & -21.6 & -21.8 & -67.6 \\
Satkhira & BR14 & 3153 & 3171 & 2434 & 1377 & 0.57 & -22.8 & -56.3 \\
Barisal & BR14 & 4397 & 2889 & 2705 & 1457 & -34.3 & -38.5 & -66.9 \\
Madaripur & BR14 & 3229 & 2606 & 2578 & 1491 & -19.3 & -20.2 & -53.8 \\
Chandpur & BR14 & 4389 & 3981 & 2801 & 1842 & -9.29 & -36.2 & -58.0 \\
Comilla & BR14 & 4678 & 4368 & 3063 & 1978 & -6.62 & -34.5 & -57.7 \\
Sylhet & BR14 & 4596 & 3764 & 4240 & 2378 & -18.1 & -7.74 & -48.3 \\
\hline
\end{tabular}

Source: Basak et.al., 2010

\section{Flooding}

Crop production is often limited during the rainy season due to excessive moisture brought about by heavy rain. Most crops are highly sensitive to flooding and genetic variation with respect to this character is limited. In general, damage to crops by flooding is due to the reduction of oxygen in the root zone which inhibits aerobic processes. Flooded crop plants accumulate endogenous ethylene that causes damage to the plants (Drew 1979). Low oxygen levels stimulate an increased production of an ethylene precursor, 1aminocyclopropane-1-carboxylic acid (ACC), in the roots. The rapid development of epinastic growth of leaves is a characteristic response to water-logged conditions and the role of ethylene accumulation has been implicated (Kawase 1981). The severity of flooding symptoms increases with rising temperatures; rapid wilting and death of tomato plants is usually observed following a short period of flooding at high temperatures (Kuo et al., 1982).

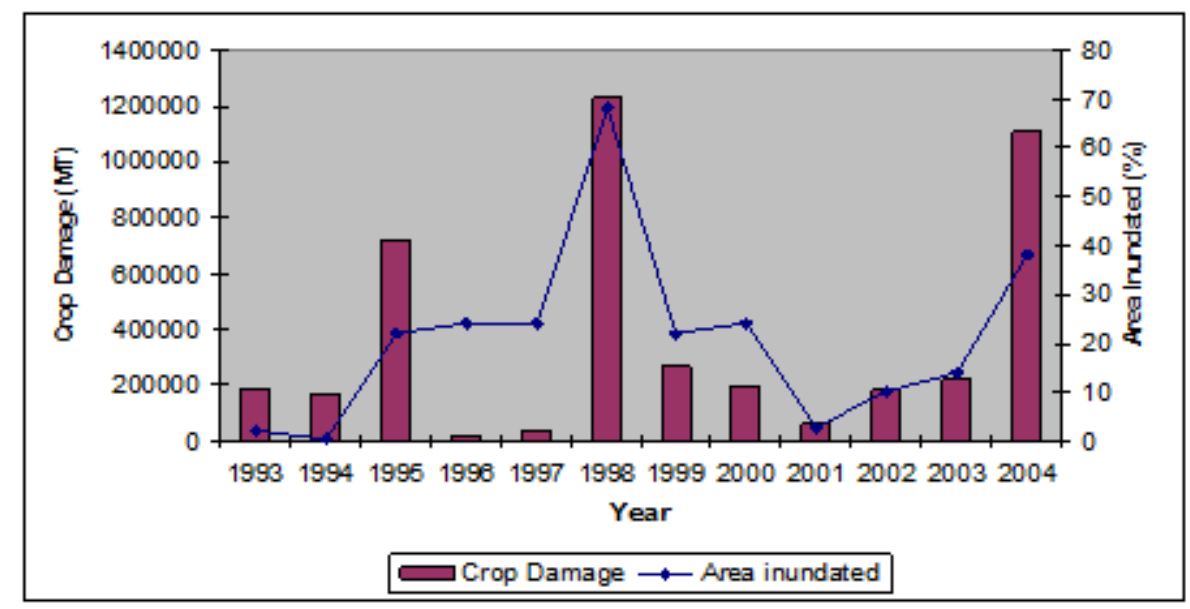

Figure 6. Crop damage (MT) due to historical flood in Bangladesh

(Source: Madhu, 2009) 


\section{Salinity}

Crop production is threatened by increasing soil salinity particularly in irrigated croplands which provide $40 \%$ of the world's food (FAO 2002). Excessive soil salinity reduces productivity of many agricultural crops, including most vegetables which are particularly sensitive throughout the ontogeny of the plant. Onions are sensitive to saline soils, while cucumbers, eggplants, peppers, and tomatoes are moderately sensitive. In hot and dry environments, high evapotranspiration results in substantial water loss, thus leaving salt around the plant roots which interferes with the plant's ability to uptake water. Physiologically, salinity imposes an initial water deficit that results from the relatively high solute concentrations in the soil, causes ion-specific stresses resulting from altered $\mathrm{K}^{+} / \mathrm{Na}^{+}$ratios, and leads to a build up in $\mathrm{Na}^{+}$and $\mathrm{Cl}^{-}$concentrations that are detrimental to plants (Yamaguchi and Blumwald 2005). Plant sensitivity to salt stress is reflected in loss of turgor, growth reduction, wilting, leaf curling and epinasty, leaf abscission, decreased photosynthesis, respiratory changes, loss of cellular integrity, tissue necrosis, and potentially death of the plant (Jones, 1986; Cheeseman, 1988). Salinity also affects agriculture in coastal regions which are impacted by low-quality and high-saline irrigation water due to contamination of the groundwater and intrusion of saline water due to natural or man-made events. Salinity fluctuates with season, being generally high in the dry season and low during rainy season when freshwater flushing is prevalent. Furthermore, coastal areas are threatened by specific, saline natural disasters which can make agricultural lands unproductive, such as tsunamis which may inundate low-lying areas with seawater. Although the seawater rapidly recedes, the groundwater contamination and subsequent osmotic stress causes crop losses and affects soil fertility. In the inland areas, traditional water wells are commonly used for irrigation water in many countries. The bedrock deposit contains salts and the water from these wells are becoming more saline, thus affecting irrigated vegetable production in these areas.

Table 11. Influence of salinity on total dry matter production ( $g / 10$ plants) of rice cultivars and their classification to salinity tolerance

\begin{tabular}{|lllll|}
\hline Variety & \multicolumn{3}{c|}{ Salinity level (ds m-1) } \\
\cline { 2 - 5 } & $\mathbf{0}$ & $\mathbf{4}$ & $\mathbf{6}$ & $\mathbf{1 2}$ \\
\hline IR 20 & 0.068 & 0.054 & 0.045 & 0.027 \\
Pokkali & 0.133 & 0.083 & 0.054 & 0.035 \\
MR 33 & 0.069 & 0.058 & 0.039 & 0.021 \\
MR68 & 0.060 & 0.044 & 0.028 & 0.018 \\
MR 84 & 0.094 & 0.048 & 0.033 & 0.024 \\
MR 52 & 0.075 & 0.057 & 0.040 & 0.028 \\
MR 211 & 0.081 & 0.065 & 0.049 & 0.035 \\
MR 219 & 0.066 & 0.052 & 0.038 & 0.024 \\
MR 220 & 0.101 & 0.052 & 0.026 & 0.014 \\
MR 232 & 0.077 & 0.054 & 0.040 & 0.031 \\
BR 29 & 0.053 & 0.040 & 0.018 & 0.004 \\
BR 40 & 0.075 & 0.054 & 0.039 & 0.023 \\
\hline
\end{tabular}

(Source: Hakim et al., 2010) 
Table 12. Tuber yield and harvest index for seven diploid potato clones and the tetraploid cultivar 'Norland' exposed to control conditions or $150 \mathrm{mM}$ salt stress for 7 days at tuber initiation

\begin{tabular}{|lll|}
\hline Clones & \multicolumn{2}{c|}{ Tuber yield $(\mathbf{g})$} \\
\cline { 2 - 3 } & Control & Stress \\
\hline Norland & 266.2 & 98.7 \\
$10908-05$ & 241.4 & 71.5 \\
F20-ID & 265.8 & 167.5 \\
$9506-04$ & 74.7 & 45.9 \\
$11374-01$ & 100.0 & 137.2 \\
$10602-02$ & 225.0 & 59.2 \\
$9788-03$ & 70.5 & 51.3 \\
Mean & 12.5 & 29.7 \\
\hline
\end{tabular}

(Source: Shaterian et.al., 2008)

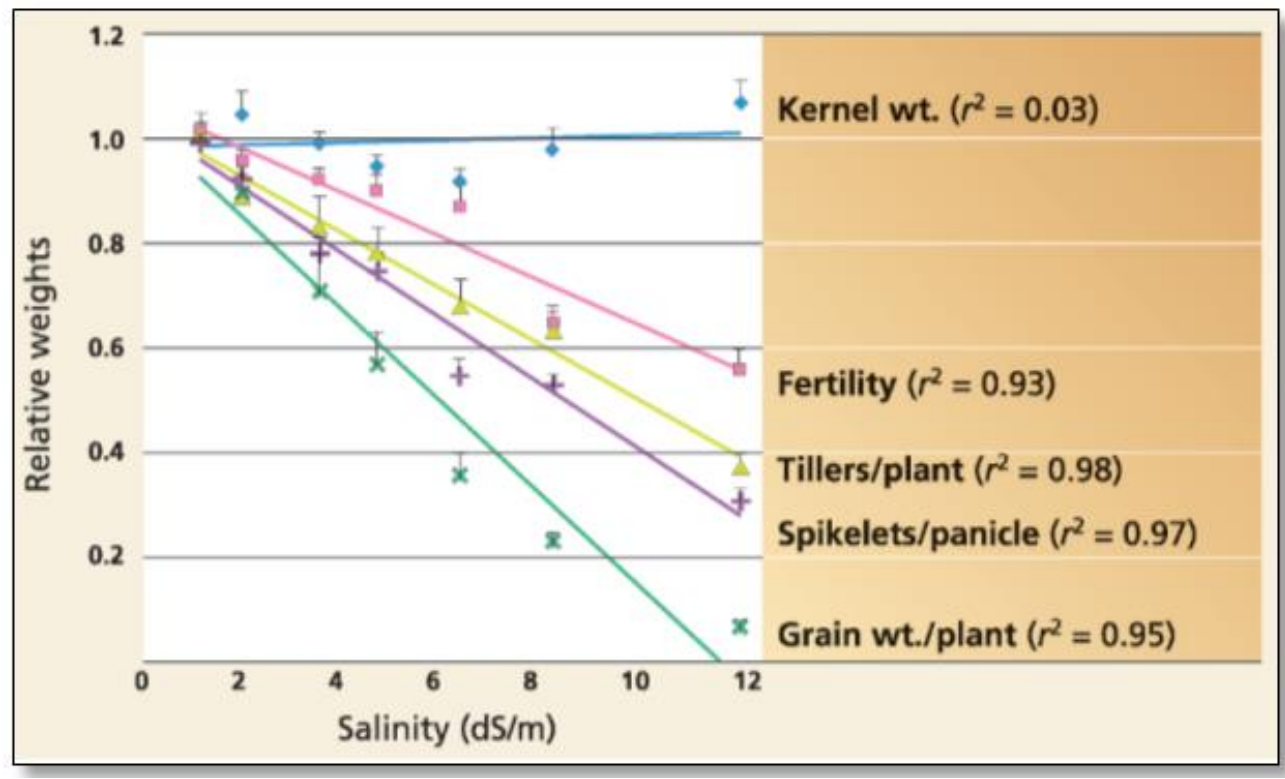

Figure 7. Relationship between salinity and various yield components of rice (Oryza sativa L. cv M202).

(Source: Zeng and Shanon, 2002)

From estimates it is seen that the main reasons of yield reduction (20-40\% yield loss) in T.Aman crop are erratic rainfall, increased intensity and frequency of drought, increased salinity, tidal surges, floods, cyclone, use of local varieties, increased incidences of pests and diseases etc in the context of climate change. Total yield loss of T.Aman crop has been estimated to about 6.93 lakh ton per year in 450,320 hectares based on last 5-10 years climate change scenarios. Similarly, average yield level of HYV Boro is being affected (30-40 $\%$ yield loss) by high temperature (causing sterility) and increased salinity and that of T.Aus/Aus crop is being affected (20-40\% yield loss) by tidal surges. Vegetables, pulses, oil seed crops and fruit crops are being affected (20-40\% yield loss) by drought, increased salinity, soil wetness, excessive rainfall and water-logging and tidal surges in most coastal districts. From the study, total crop loss for major crops (viz. cereals, potato, pulses, oil seeds, vegetables, spices and fruit crops) due to different climate risks has been estimated to about 14.05 lakh tons per year based on last 5-10 years of climate change scenarios in ten districts. But the people are to live with these climatic vulnerabilities and risks in the coastal region. 


\section{Climate change scenarios on the coastal regions of Bangladesh}

Table 13. Crop loss/yield reduction due to climate risk factors

\begin{tabular}{|c|c|c|c|c|c|}
\hline Crop & $\begin{array}{l}\% \text { yield } \\
\text { reduction }\end{array}$ & District & $\begin{array}{l}\text { Total areas } \\
\text { (in ha) affected }\end{array}$ & $\begin{array}{l}\text { Total yield } \\
\text { loss ‘000' MT }\end{array}$ & Major Climatic Risks \\
\hline \multirow[t]{10}{*}{ T. Aman } & $40-60$ & Cox's Bazar & 35,500 & 71.00 & $\begin{array}{l}\text { Drought, flash floods, salinity, } \\
\text { erosion, tidal surges, pests \& } \\
\text { diseases }\end{array}$ \\
\hline & $20-40$ & Patuakhali & 76,200 & 114.30 & $\begin{array}{l}\text { Drought, water-logging, tidal } \\
\text { floods, pests and diseases }\end{array}$ \\
\hline & $20-40$ & Baraguna & 27,500 & 41.25 & $\begin{array}{l}\text { Drought, flood, pests \& } \\
\text { diseases }\end{array}$ \\
\hline & $20-40$ & Pirojpur & 25,600 & 38.40 & $\begin{array}{l}\text { Flood, drought, tidal surge, } \\
\text { pests }\end{array}$ \\
\hline & $20-40$ & Barisal & 57,700 & 86.62 & $\begin{array}{l}\text { Flood, water-logging, drought, } \\
\text { pests \& diseases }\end{array}$ \\
\hline & $20-40$ & Noakhali & 59,950 & 89.93 & $\begin{array}{l}\text { Drought, flood, water, logging, } \\
\text { pests \& diseases }\end{array}$ \\
\hline & $20-40$ & Satkhira & 35,700 & 53.55 & $\begin{array}{l}\text { Drought, water-logging, } \\
\text { erosion, pests }\end{array}$ \\
\hline & $20-40$ & Khulna & 28,850 & 43.27 & $\begin{array}{l}\text { Cyclone, water-logging, } \\
\text { salinity, pests }\end{array}$ \\
\hline & $20-40$ & Bagerhat & 61,270 & 91.90 & $\begin{array}{l}\text { Drought, flood, river erosion, } \\
\text { pests }\end{array}$ \\
\hline & $20-40$ & Bhola & 42,000 & 63.00 & $\begin{array}{l}\text { Drought, tidal flood, cyclone, } \\
\text { pests }\end{array}$ \\
\hline T. Aus & $20-40$ & All districts & 75,000 & 112.50 & $\begin{array}{l}\text { Submergence, drought, } \\
\text { salinity, Fe toxicity, river \& } \\
\text { ground water salinity, cyclone, } \\
\text { pests \& diseases }\end{array}$ \\
\hline HYV Boro & $20-40$ & All districts & 150,000 & 300.00 & $\begin{array}{l}\text { Drought, salinity, Fe toxicity, } \\
\text { river \& ground water salinity, } \\
\text { cyclone }\end{array}$ \\
\hline $\begin{array}{l}\text { Potato, Sweet } \\
\text { Potato }\end{array}$ & $40-60$ & All districts & 28,055 & 140.25 & $\begin{array}{l}\text { Short winter, clayey soils, } \\
\text { salinity, fogginess. Average } \\
\text { yield }=10-12 \mathrm{t} / \mathrm{ha}\end{array}$ \\
\hline $\begin{array}{l}\text { Pulses } \\
\text { (Khesari, } \\
\text { M.bean) }\end{array}$ & $20-40$ & All districts & 201,850 & 60.55 & $\begin{array}{l}\text { Untimely rainfall, soil wetness, } \\
\text { drought, salinity, Pests \& } \\
\text { diseases }\end{array}$ \\
\hline $\begin{array}{l}\text { Oilseed Crops } \\
\text { (Mustard,sesa } \\
\text { me, G.nut) }\end{array}$ & $20-40$ & All districts & 63,750 & 19.12 & $\begin{array}{l}\text { Late/short winter, salinity, } \\
\text { clayey soils, Pests \& diseases }\end{array}$ \\
\hline $\begin{array}{l}\text { Spice Crops } \\
\text { (Chilli, Onion, } \\
\text { Garlic) }\end{array}$ & $20-40$ & All districts & 53,630 & 26.81 & $\begin{array}{l}\text { Early rainfall, soil wetness, } \\
\text { salinity, pests and diseases. }\end{array}$ \\
\hline \multirow{2}{*}{$\begin{array}{l}\text { Fruit crops } \\
\text { (banana,papa } \\
\text { ya, water } \\
\text { melon, amra, } \\
\text { guava, amra } \\
\text { etc) }\end{array}$} & $20-40$ & All districts & 10,625 & 53.12 & $\begin{array}{l}\text { Erratic rain, drought, high } \\
\text { temperature, salinity, tidal } \\
\text { flood, water-logging, pests \& } \\
\text { diseases and cyclone }\end{array}$ \\
\hline & & & Total & $1,405.57$ & \\
\hline
\end{tabular}

All districts= Khulna, Bagerhat, Satkhira, Barisal, Bhola, Barguna, Pirojpur, Patuakhali, Cox's Bazar and Noakhali. (Source: Miah, 2010) 
Table 14. Adaptation practices for sustainable crop production in the context of climate change

\begin{tabular}{|c|c|}
\hline District & Recommended adaptation practices \\
\hline 1. Cox's bazaar & $\begin{array}{l}\text { Sorjan system of cultivating year round vegetables, spices and fruits on raised beds and } \\
\text { creeper vegetables on bed edges, Fish culture in ditches during wet months, Introduction } \\
\text { of salt tolerant crop varieties, Encourage fruits and vegetables gardening } \\
\text { Introduction of high value vegetable crop varieties (hybrid cucumber, ladies finger, chillis } \\
\text { etc) as relay cropping in vegetable growing areas. } \\
\text { Embankment repair and introduction of late T.Aman variety }\end{array}$ \\
\hline 2. Noakhali & $\begin{array}{l}\text { Excavation of canals ponds for saline free water and introduction of salt tolerant } \\
\text { varieties, Promote introduction of salt-tolerant pulses and oil seed crops (viz. cowpea, } \\
\text { soybean, mungbean, ground nut etc.) } \\
\text { Introduce floating bed agriculture in water-logged areas. } \\
\text { Drainage improvement, introduce short duration and salt-tolerant crop varieties. } \\
\text { Introduce standing water (submergence var.) boro cultivation } \\
\text { Making high embankment and introduce salt tolerant varieties }\end{array}$ \\
\hline 3. Barisal & $\begin{array}{l}\text { Sorjan system of cultivating year round vegetables, spices and fruits on raised beds and } \\
\text { creeper vegetables on bed edges and cultivation of fish in ditches during wet months. } \\
\text { Introduce submergence tolerant rice varieties (BRRIdhan-51,52, BINAdhan-11,12) } \\
\text { Popularize floating bed agriculture. } \\
\text { Zero tillage (potato, maize) and floating bed agriculture. } \\
\text { Introduce submergence tolerant rice varieties }\end{array}$ \\
\hline 4. Barguna & $\begin{array}{l}\text { Introduction of salt tolerant pulse crops (mungbean, cowpea, soybean, ground nut, sweet } \\
\text { potato, chilli) } \\
\text { Sorjan system of cultivating year round vegetables, spices \& fruits on raised beds and } \\
\text { creeper vegetables on bed edges and cultivation of fish in ditches during wet months. } \\
\text { Introduction of drought and salt-tolerant crop varieties creating facilities of irrigation in } \\
\text { fallow lands. } \\
\text { Introduction of zero tillage (potato) } \\
\text { Digging ponds and canals for rain water harvest. }\end{array}$ \\
\hline 5. Satkhira & $\begin{array}{l}\text { Introduction of salt-tolerant crop varieties in salt affected areas } \\
\text { - rice crops (BRRIdhan- } 44,47 \text { BINAdhan- } 8,10 \text { ) } \\
\text { - Utilization of fallow bunds under gher areas for year round vegetable cultivation, } \\
\text { Popularization of zero tillage (potato, maize) } \\
\text { Sorjan system of cultivating year round vegetables, spices and fruits on raised beds and } \\
\text { creeper vegetables on bed edges and cultivation of fish in ditches during wet months, } \\
\text { Floating bed agriculture in water-logged areas. }\end{array}$ \\
\hline
\end{tabular}

Source: Miah, 2010 
Trends of Crop production per hectare (Satkhira district) due to climate change are shown graphically below: (Figures 8-11)
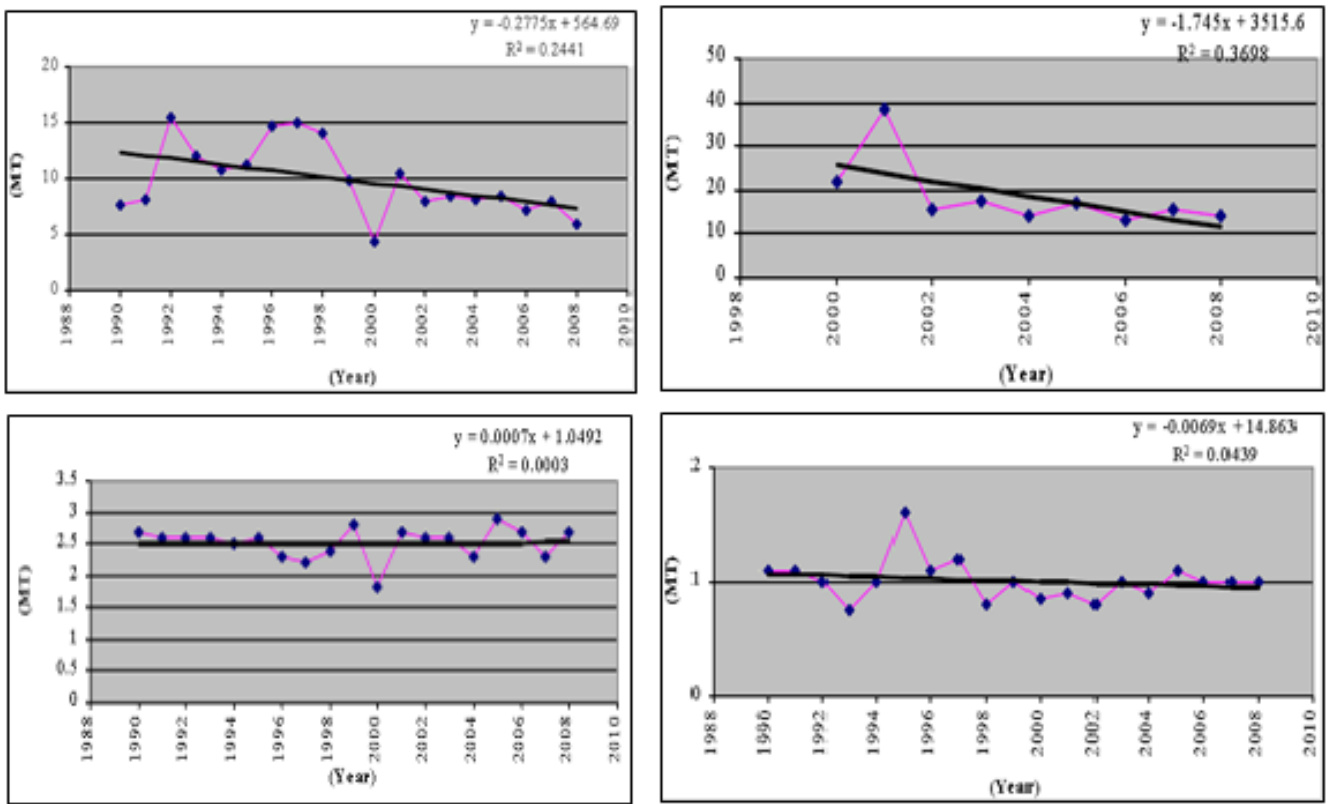

Figure 8. Trend of T Aman (HYV) production Figure 10. Trend of Onion production.

Figure 9. Trend of sesame (HYV) production.

Figure 11.Trend of Winter vegetables production.

(Source: Miah, 2010)

\section{CONCLUSION}

Climate change can boost up certain crop's production and also can decrease particulars yield. Therefore it is advised to cultivate stress tolerant crops and change production technology in vulnerable areas such as coastal region and flood prone areas. Bangladesh is not responsible for climate change or global warming, but is severely affected. To cope with the present situation of climate change in crop sector of Bangladesh, research should be conducted for introducing of salinity and flood tolerant variety of crops. Otherwise, the food security will be hampered in the near future.

\section{REFERENCES}

1. Abdalla AA and K Verderk, 1968. Growth, flowering and fruit set of tomato at high temperature. The Netharlands Journal of Agricultural Science, 16: 71-76.

2. Agarwala S, T Ota, AU Ahmed, J Smith and M van Aalst, 2003. Development and Climate Change in Bangladesh: Focus on the Coastal Flooding and the Sundarbans, Organization for Economic Cooperation and Development (OECD), Paris. pp. 34-67

3. Anonymous. 2012. Climate change and agriculture- Wikipedia, the free encyclopedia. (Cited fromhttp://www.en.wikipedia.org/wiki/Climate_change_and_agriculture)

4. AVRDC, 1990. Vegetable Production Training Manual, Asian Vegetable Research and Training Center. Shanhua, Tainan, $447 \mathrm{pp}$.

5. Baker JT and LH Jr. Allen, 1993a. Contrasting crop species responses to $\mathrm{CO}_{2}$ and temperature: Rice, soybean, and citrus. Vegetatio 104/105: 239-260. Also: pp. 239-260. In: $\mathrm{CO}_{2}$ and Biosphere. (Advances in Vegetation Science 14). J. Rozema, H. Lambers, S.C. van de Geijn and M.L. Cambridge (eds.). Kluwer Academic Publishers, Dordrecht.

6. Baker JT and LH Jr. Allen, 1993b. Effects of $\mathrm{CO}_{2}$ and temperature on rice: A summary of five growing seasons. Journal of Agricultural Meteorology, (Japan), 48: 575-582.

7. Basak JK, MA Ali, N Islam and A Rashid, 2010. Assessment of the effect of climate change on boro rice production in Bangladesh using DSSAT model. Journal of Civil Engineering (IEB), 38: 95-108. 
8. Bell GD, MS Halpert, RC Schnell, RW Higgins, J Lowrimore, VE Kousky, R Tinker, W Thiaw, M Chelliah and A Artusa, 2000. Climate Assessment for 1999. Supplement, Bulletin of the American Meteorological Society, 81: 22-52

9. Bray EA, J Bailey-Serres and E Weretilnyk, 2000. Responses to abiotic stresses. In: Gruissem W, Buchannan B, Jones R (eds) Biochemistry and molecular biology of plants. ASPP, Rockville, MD. pp. 1158-1249.

10. Burke M, E Miguel, S Satyanath, J Dykema and D Lobell, 2009. Warming increases risk of civil war in Africa. Proceedings of the National Academy of Sciences USA 106, 20670-20674.

11. Capiati DA, SM País and MT Téllez-Iñón, 2006. Wounding increases salt tolerance in tomato plants: evidence on the participation of calmodulin-like activities in cross-tolerance signaling. Journal of Experimental Botany, 57: 2391-2400.

12. CGIAR, 2003. Applications of molecular biology and genomics to genetic enhancement of crop tolerance to abiotic stresses - a discussion document. Interim Science Council Secretariat, FAO. pp. 19-58

13. Cheeseman JM, 1988. Mechanisms of salinity tolerance in plants. Plant Physiology, 87: 57-550.

14. Drew MC, 1979. Plant responses to anaerobic conditions in soil and solution culture. Current Advances in Plant Science, 36: 1-14.

15. Erickson, AN. Markhart AH, 2002. Flower developmental stage and organ sensitivity of bell pepper (Capsicum annuum L) to elevated temperature. Plant Cell \& Environment, 25: 123-130.

16. FAO, 2004. Impact of climate change on agriculture in Asia and the Pacific. Twenty-seventh FAO Regional Conference for Asia and the Pacific. Beijing, China, 17-21 May 2004.

17. FAO, 2005. Summary of the World Food and Agricultural Statistics. FAO, Rome. pp. 334-337. Available at: http://faostat.fao.org (accessed 4 August 2009).

18. Hakim MA, AS Juraimi, M Begum, MM Hanif, MR Ismail and A Selamat, 2010. Effect of salt stress on germination and early seedling growth of rice (Oryza sativa L.). African Journal of Biotechnology, 9: 1911-1918.

19. Hazra P, HA Samsul, D Sikder and KV Peter, 2007. Breeding tomato (Lycopersicon Esculentum Mill) resistant to high temperature stress. International Journal of Plant Breeding, 1: 21-26

20. Hijmans RJ, 2003. The Effect of Climate Change on Global Potato Production. American Journal of Potato Research, 80: 271-280.

21. IPCC, 2007. IPCC Fourth Assessment Report: Climate Change 2007. IPCC, Geneva.

22. IPCC, 2009. The Intergovernmental Panel on Climate Change. Available at: http://www.ipcc.ch (accessed 22 September 2009).

23. IPCC, 2001. Climate change 2001. Impacts, adaptation and vulnerability. Intergovermental Panel on Climate Change. New York, USA.

24. IPCC, 2007: Summary for Policymakers. In: Climate Change 2007: The Physical Science Basis. Contribution of Working Group I to the Fourth Assessment Report of the Intergovernmental Panel on Climate Change [Solomon, S., D. Qin, M. Manning, Z. Chen, M. Marquis, K.B. Averyt, M.Tignor and H.L. Miller (eds.)]. Cambridge University Press, Cambridge, United Kingdom and New York, NY, USA.

25. Jones JW, G Hoogenboom, CH Porter, KJ Boote, WD Batchelor, LA Hunt, PW Wilkens, U Singh, AJ Gijsman and JT Ritchie, 2003. The DSSAT cropping system model. European ournal of Agronomy, 18: $235-236$.

26. Jones RA, 1986. The development of salt-tolerant tomatoes: breeding strategies. Acta Horticulturae, 190: Symposium on Tomato Production on Arid Land. pp. 134-156.

27. Karim Z, SG Hussain, and M Ahmed, 1998. Assessing Impact of Climate Variations on Food grain Production in Bangladesh. Water Air and Soil Pollution, 92: 53-62.

28. Kawase M, 1981. Anatomical and morphological adaptation of plants to waterlogging. Horticultural Science, 16: 30-34.

29. Khan, HM, M Sarwar and J Islam, 2008. Climate Change and Strategic Adaptation Provisions for Coastal Bangladesh, IDB Bhaban, Dhaka, Bangladesh. pp. 28-61

30. Kuo DG, JS Tsay, BW Chen and PY Lin, 1982. Screening for flooding tolerance in the genus Lycopersicon. Horticultural Science, 17: 76-78. 
31. Madhu MK, 2009. Climate Change and Agriculture in the South-West. (Available on line at http://www.teacher.buet.ac.bd/akmsaifulislam/climaterisk/student/Group-2.ppt).

32. McWilliam JR, 1986. The national and international importance of drought and salinity effects on agricultural production. Australian Journal of Plant Physiology, 13: 1-13.

33. Mertz O, K Halsnaes, JE Olesen and K Rasmussen, 2009. Adaptation to climate change in developing countries. Environmental Management, 43: 743-752.

34. Miah M U, 2010. Assessing Long-term Impacts of Vulnerabilities on Crop Production Due to Climate Change in the Coastal Areas of Bangladesh, Bangladesh Center for Advanced Studies, Dhaka. pp: 12-128.

35. Rahman M, 2013. Climate Change, Disaster and Gender Vulnerability: A Study on Two Divisions of Bangladesh. American Journal of Human Ecology, 2: 72-82.

36. Reddy VR, V. Ambumozhi and KR Reddy, 2005. Achieving Food Security and Mitigating Global Environmental Change. (Available On line at www.ars.usda.gov/SP2UserFiles/Place/.../BANGKOK_2005.ppt)

37. Reynolds MP, 2010. Climate change and Crop production. CAB International, Nosworthy Way, Wallingford, Oxfordshire OX10 8DE, UK. pp. 1-37.

38. Sato S, MM Peet and JF Thomas, 2002. Determining critical pre- and post-anthesis periods and physiological process in Lycopersicon esculentum Mill. Exposed to moderately elevated temperatures. Journal of Experimental Botany, 53: 1187-1195.

39. Shaterian J, DR Waterer, H De Jong and KK Tanino, 2008. Methodologies and Traits for Evaluating the Salt Tolerance in Diploid Potato Clones. American Journal of Potato Research, 85: 93-100.

40. Singh P, AVR Kesava Rao and K Srinivas, 2009. Role of Crop Simulation Models in Assessing Impacts of Climate Change and Evaluating Adaptation Options. ICRISAT. pp. 124-131.

41. Stevens MA and J Rudich, 1978. Genetic potential for overcoming physiological limitations on adaptability, yield, and quality in tomato. Horticultural Science, 13: 673-678.

42. Sultana W, MA Aziz and F Ahmed, 2008. Climate Change: Impact on Crop Production and its Coping Strategies. Agronomy division, BARI, Gazipur. pp. 2-45. (Available on line at: http://www.wamis.org/agm/meetings/rsama08/Bari103-Sultana_Coping_Strategies.pdf)

43. Tubiello FN and G Fischer, 2007. Reducing climate change impacts on agriculture: Global and regional effects of mitigation, 1990-2080. Technological Forecasting and Social Change, 74:10301056.

44. United Nations Population Division Department of Economic and Social Affairs (DoEaSA) (2009) World Population Prospects: the 2008 Revision. pp. 3-86. Available at: http://esa.un.org/unpp

45. Wang H, Y He and B Qian, 2011. Impact of Climate Change on Wheat Production for Ethanol in Southern Saskatchewan, Canada. World Renewable Energy Congress 2011, Linkoping, Sweden. pp 647-648.

46. Weis E and JA Berry 1988. Plants and high temperature stress. Society of Experimental Biology, pp 329-346.

47. World Bank, 2000. Bangladesh, Climate Change and Sustainable Development. Report No 21104BD. pp. 5-59

48. Yamaguchi $T$ and $E$ Blumwald, 2005. Developing salt-tolerant crop plants: challenges and opportunities. Trends in Plant Science, 10: 616-619.

49. Zeng $L$ and $M C$ Shannon, 2000. Salinity effects on seedling growth and yield components of rice. Crop Science, 40: 996-1003.

50. Zhang DD, P Brecke, HF Lee, YQ He and J Zhang, 2007. Global climate change, war and population decline in recent human history. Proceedings of the National Academy of Sciences USA 104, 1921419219. 